\title{
On the Investment Benefit and Risk Assessment of Resettlement Housing Construction
}

\author{
Yi Chong Xu \\ College of Economics and Management, Zhejiang University of Technology,Hangzhou,China
}

2579284882@qq.com

Keywords: Removal settlement housing; Cost composition; Influencing factors; Investment benefit; Risk assessment

\begin{abstract}
With the development of economy and the progress of society, the quality requirements of resettlement housing are increasing, which has brought great challenges to the resettlement housing construction. How to control the cost while ensuring the quality has become a concern of enterprises. This paper analyzes the characteristics of resettlement housing cost control, and illustrates the content of cost composition as well as its influence on the final prices.
\end{abstract}

\section{Introduction}

The quality and cost issues of resettlement housing are directly related to social harmony and stability, which must draw attention from government departments and relevant entities[1][2]. The government improves the living standards of ordinary people through removal and settlement while ensuring the smooth progress of urban construction[3][4]. With the development of times, cost control problems of resettlement housing have become complex with growing aspects involved. As a result[5][6], previous corporate management modes fail to meet the requirements of resettlement housing construction[7][8]. Besides, undertakers of resettlement housing projects -- real estate developers must control development cost and achieve benefits.

\section{Cost composition features and contributing factors of resettlement housing}

Characteristics. The section headings are in boldface capital and lowercase letters. Second level headings are typed as part of the succeeding paragraph (like the subsection heading of this paragraph)[9]. Development cost control of resettlement housing projects runs through the whole process, from project approval to delivery .Therefore, all development phases of the project should be controlled. The problem of only emphasizing the costs of construction phase but ignoring cost contro of the other stages should be avoided. To meet the requirements for capital expenditure, all payments of the contract, cost amount and payment-making time should all be monitored.

Cost objective is not isolated and it is valuable only when considering the quality, progress, and resource consumption. Project managers should not merely emphasize on cost control but ignore the other objectives. During project implementation, cost control and quality management, schedule management, security management must be synchronized. Generally, over-expenditure of costs is not caused by cost control, but by adjustment of objectives or other factors.

To better control the whole project cost expenditure, control has to be taken step by step starting from the time of each cost expenditure and each sub project.

Contributing factors. Resettlement housing land is mainly allocated by government, so real cost of the land is rather limited while the main costs include demolition and resettlement subject largely to policy and market influences[10].

Upfront costs include engineering design costs, various prescribed costs, and so on. Design stage has significant influence on the development costs of resettlement housing projects and is key to cost control[11]. As design determines the project cost while budget and resettlement can only measure but can not change the project cost, the design stage should be focused on. It is effective to control the cost of resettlement housing project. Apartment layout should be determined and designed according 
to demolition households and apartment layout requirements. Efforts should be made to reduce and prevent the increase of costs resulting from contraction with the contract. In the design stage, schemes should be fully demonstrated and optimized not only from the perspective of technology, but also combining technical and economic factors so a. Cost-benefit analysis method can be adopted in the selection of schemes. In the premise of satisfying the engineering structure and usage function, design schemes should be selected according to economic indicators.

Checking the unit price (per square meter ) of resettlement housing, construction and installation costs account for a larger percentage. The whole project implementation process sees constant growth of investment in construction and installation, which should be the focus of cost control. Contract management must be strengthened in terms of Material price, construction organization and design, construction plan, change in construction process and other factors increase construction costs. Contract is important proof for payment and settlement. Only with due attention paid to contract terms would future disputes be avoided and costs be reduced. Fixed total price contract is recommended, for reducing cost increases caused by material price changes. Meanwhile, design changes should be strictly controlled. Engineering pricing clause should be clearly stipulated in the contract. Price adjustment clause should be emphasized and market inquiries should be employed for unset prices.

Construction funds of settlement housing are mostly bank loans, and interests have to be paid. Financial costs can be reduced when construction companies make proper use of funds while strengthening project management.

\section{A Case study of costs and benefits in resettlement housing construction}

A resettlement housing project is located in north of Hangzhou City, with its land allocated. It has a total area of about $27600 \mathrm{~m}^{2}$, of which residential land is $23230 \mathrm{~m}^{2}$. The planned building area is $69690 \mathrm{~m}^{2}$ (above ground). The total residential construction area is $63581 \mathrm{~m}^{2}$, with a supporting construction area of $5779 \mathrm{~m} 2$. The construction period is three years.

Estimation of construction costs. Land costs are mainly for demolition and relocation According to the costs of similar project around, land costs of this project are estimated at about $60,000,000$ Yuan. Preliminary costs including design fees and prescribed costs are totaled about 18,500,000 Yuan. Project construction costs include housing construction engineering, environmental engineering, intelligent engineering and equipments. Considering policy requirements and market factors, such as increased costs in energy saving and environmental protection in the main project, the construction costs are estimated at about 170,000,000 Yuan. Considering the reality of this ongoing resettlement housing, unforeseen expenses are considered as $1.5 \%$ of the project cost. According to the financing plan, expected loan for the first year is 50,000,000 Yuan for a period of 2.5 years, loan for the second year is 100,000,000 Yuan for a period of 2 years, both with an annual interest rate of $8 \%$.

Investment plan and fund raising.Investment plan and fund raising are shown in table 1 . The investment is mainly made in the first 2 years, including construction cost and interest expense, and cost recovery is realized through sales of resettlement housing at the last year. Fund raising is mainly obtained through bank loans, so financial costs are high.

Table 1 Investment plan and fund raising

unit: Million Yuan

\begin{tabular}{|l|l|l|l|l|l|}
\hline Project & First year & Second year & Third year & Forth year & Total \\
\hline Total investment & 9714 & 9073 & 7073 & 3237 & 29097 \\
\hline Project construction cost & 9627 & 8900 & 6900 & 3150 & 28577 \\
\hline Excluding interest & 9427 & 7700 & 5700 & 3150 & 25977 \\
\hline Interest & 200 & 1200 & 1200 & & 2600 \\
\hline Raised funds & 16450 & 10000 & & 36850 & 63300 \\
\hline Own capital & 11450 & & & & 11450 \\
\hline Booking income & & & & 36850 & 36850 \\
\hline Bank borrowings & 5000 & 10000 & & & 15000 \\
\hline
\end{tabular}


Analysis of project returns. The resettlement housing is repurchased by the government, so sales is not sensitive . Related analyses are only made on the price and profit. Assuming that the sales of shops and parking spaces completely reach the expected target, then making break-even analysis is made on housing price. The Relationship between the price and profit per unit area is shown in table Table 2 and Fig.1. Fig. 1 shows that the profit rate is directly proportional to the housing prices. The break-even point is 4100 Yuan per square meter, while the sales price reaches 5000 Yuan per square meter, with a profit margin of $9.81 \%$. The sale price will not be too high for resettlement housing, so the price per unit area is determined at 4500 Yuan, with a profit rate of $4.78 \%$.

Table 2 Relationship between price and profit

\begin{tabular}{|c|c|c|c|c|}
\hline $\begin{array}{c}\text { Housing price } \\
\left(\text { Yuan } / \mathrm{m}^{2}\right)\end{array}$ & $\begin{array}{l}\text { profit ( Million } \\
\text { Yuan) }\end{array}$ & Profit rate (\%) & $\begin{array}{l}\text { Net profit (Million } \\
\text { Yuan) }\end{array}$ & Net interest rate (\%) \\
\hline 4100 & 750 & 2.41 & 0 & 0 \\
\hline 4300 & 1949 & 6.02 & 806 & 2.49 \\
\hline 4500 & 3147 & 9.35 & 1609 & 4.78 \\
\hline 4800 & 4945 & 13.90 & 2813 & 7.91 \\
\hline 5000 & 6144 & 16.67 & 3616 & 9.81 \\
\hline 5200 & 7342 & 19.26 & 4419 & 11.59 \\
\hline 5500 & 9140 & 26.14 & 5624 & 16.08 \\
\hline
\end{tabular}

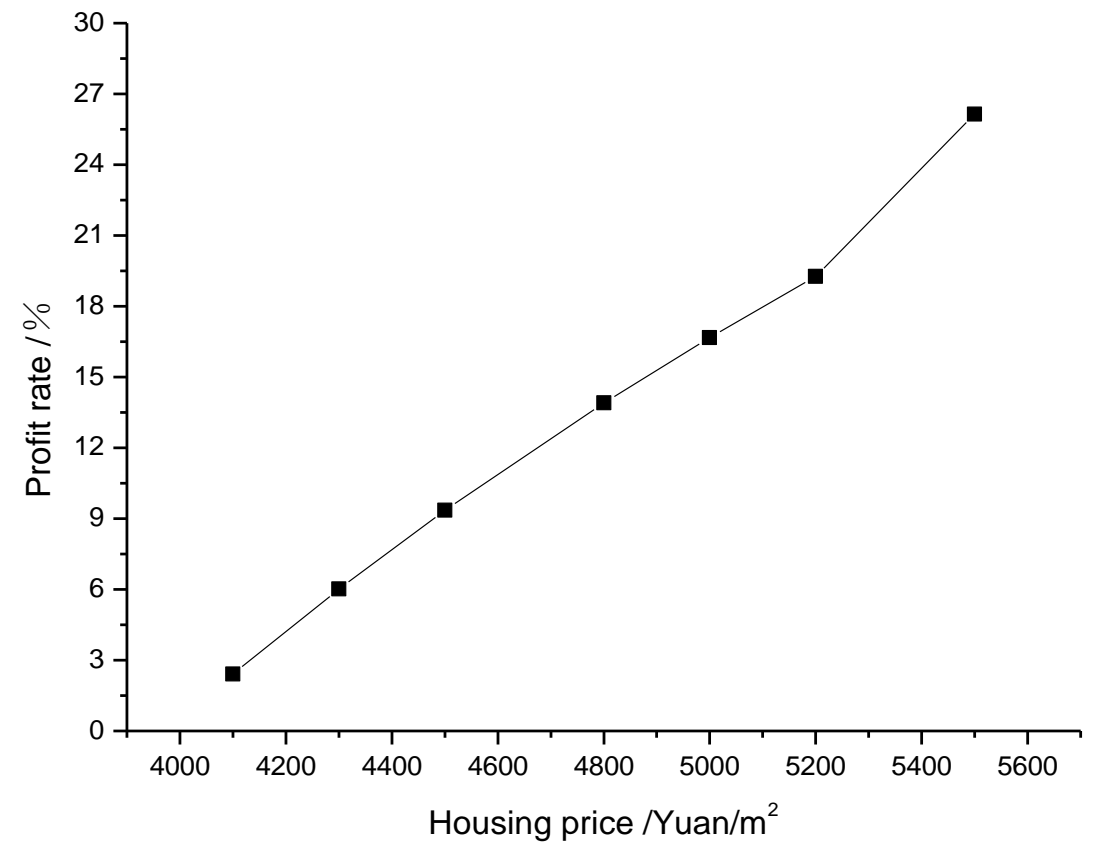

Figure. 1 The relationship between housing price and profit rate

Resettlement housing is a kind of commodity housing with social security nature and economic proposition, which means that residence price is moderate and can be adapted for low-income families compared with market price. As long as market demands on size, apartment layout and other aspects are fully considered, the market risk of such projects would be very low. Resettlement housing has the characteristics of economy and applicability. Applicability means that practical effects in housing design and construction standards should be emphasized, rather than lower 
construction standards. Therefore, plans for affordable housing construction should be well made to reduce and prevent risks in management. In construction management, controlling development and construction costs, reducing investment costs, are also important to lowering project risks.Fund raising channels of this project funds mainly include own funds, bank loans, and sale income. Market risk of this project is low, and cost recovery is guaranteed. Consequently, economic benefits could be achieved through the effective use of financial leverage and avoiding financial risks by strengthening construction management, reducing capital-holding costs, and advancing sales receivables.

\section{Conclusion}

Development cost control of resettlement housing projects is a dynamic process as well as a comprehensive task. Resettlement housing project developers should apply the knowledge of modern cost control and management, constantly study and explore new ideas, new methods, which is of prominent significance to cost control and economic benefits of resettlement housing construction.

\section{References}

[1] Y.Xiaosong: Chongqing Architecture Vol. 63 (2009) 29.

[2] F.Xuzhuang., D.Danshen: Huazhong Architecture Vol. 23 (2011) 96-100.

[3] L.Junping.,M.Yun:Journal of graduate school of chinese academy of social sciences Vol. 186 (2011) 50-56.

[4] M. Wei: Value Engineering Vol.13 (2012) 112-114.

[5] CHEN Fei-qiang: Journal of Northwest A\&F University(Social Science Edition) Vol. 12 (2012) 120-125.

[6] WU Fangfei., BI Yan.,WANG Huili: Journal of Shenyang Jianzhu University(Social Science) Vol. 8 (2006) 368-370.

[7] Wang Xue-zhong: Research on the Benefit Assignment of the Countryside Collective Land's Drafting and Relocating[D], National University of Defense Technology, Changsha(2006).

[8] Zeng Wei: Research of the Removing Compensation of Urban Building[D],Guangxi University,Nanning(2007).

[9] He Zhaiping: Operational Modes of Social Relationship Networks during House removing:Case Study of House removing in BY Community of Shan Dong Province[D],Tianjin Normal University, Tianjin(2014).

[10] SHI Ke-chun: Journal of Kunming University of Science and Technology(Social Sciences) Vol. 10 (2010) 52-56.

[11] Chang Qing: Architectural Design Management Vol. 195 (2013) 30-33. 